\title{
The context of special pedagogy: practical inclusive education or simulated inclusive education?
}

\begin{abstract}
Krystyna Barłóg, The centex of special pedagogy: implementedinclusive education or simulated inclusive education? Interdisciplinary Contexts of Special Pedagogy, no. 26, Poznań 2019. Pp. 125-142. Adam Mickiewicz University Press. ISSN 2300-391X. e-ISSN 2658-283X. DOI: https:// doi.org/10.14746/ikps.2019.26.06

In many contexts of contemporary special education, its main present and future challenges are the implementation of effective inclusive education, the preparation of the required conditions, space and relations of safe functioning of a child with disabilities or special education needs together with healthy, able-bodied peers. Are the long-standing dreams of parents and many special educators regarding the equal rights of all people with disabilities, and in particular the right to education closest to the child's place of residence, genuinely achieved nowadays? The diagnosis of selected municipal schools shows the real situation of the implementation of inclusive education. Are these successes already being achieved today? Or is it still a educational reality?
\end{abstract}

KEY WORDS: special pedagogy, inclusive education, context, children with disabilities

\section{Introduction}

Irrespective of the development of special paedagogy, one can still see the need for many changes that are supposed to bring disabled persons, in particular children and youths, closer to normalisa- 
tion situations, in particular those securing full access to schools and to life within a specific community. One needs to conclude today already that in many aspects of life, changes for the better are occurring that are improving on the difficulties in the lives of disabled people and their families. ${ }^{1}$ One can see, however, that in certain situations, disabled people may be excluded, isolated or rejected. Some of them may still experience many negative things only because that certain communities uphold the tendency of exclusion and marginalisation. ${ }^{2}$ However, the basis of inclusive education encompasses the belief of the necessity to counteract the discrimination of the disabled, as is expressed in the opposition against the treatment of disabled persons less favourably. Many activities are undertaken to equalise chances and participation. ${ }^{3}$ Speaking from the historic point of view, the entire philosophy of inclusive education was implemented in practice over forty years ago in Scandinavia as the need to provide so-called normalisation. In the 1960s and 1970s, it was popular in the United States, with the assumption that disabled children should be taught in an environment, in which there are as few limitations as possible., ${ }^{4,5}$ In June of 1994 in Salamanca, a statement was signed on inclusive education on the international scene, whereby it was assumed that persons with special

${ }^{1}$ I. Chrzanowska, Pedagogika specjalna Oficyna Wydawnicza „Impuls”, Kraków, 2015, p. 120.

2 D.D. Smith, Pedagogika specjalna, sc. ed. by A. Firkowska-Mankiewicz, G. Szumski, Wydawnictwo APS, Warszawa 2009, pp. 31-71.

${ }^{3}$ P. Bayliss, Edukacja wtaczajaca, [in:] Od nauczania integracyjnego do szkoty równych szans, J. Bogucka, D. Żyro (ed.), Wydawnictwo CMPPP MEN, Warszawa 2002, p. 21.

${ }^{4}$ G. Szumski, Wokót edukacji wtaczającej. Efekty kształcenia uczniów z niepetnosprawnościa intelektualna $w$ stopniu lekkim $w$ klasach specjalnych, integracyjnych $i$ ogólnodostępnych, Wydawnictwo Akademii Pedagogiki Specjalnej im. Marii Grzegorzewskiej, Warszawa 2010.

${ }^{5} \mathrm{~A}$. Zamkowska, Wsparcie edukacyjne uczniów z upośledzeniem umystowym w stopniu lekkim w różnych formach ksztatcenia na pierwszym etapie edukacji, Wydawnictwo Politechniki Radomskiej, Radom 2009. 
needs have to have access to typical schools, which are the best resource for counteracting discrimination and the establishment of an integrated society. 6,7

In the opinion of Iwona Chrzanowska, the consideration of issues of disability in the context of the risk of exclusion, or exclusion itself, is nothing new in the area of special education or sociology. ${ }^{8}$ For centuries, disabled people have seen oppressive behaviour by fully able people. They were accompanied, among others, by terror, fear, distrust, mercy and others. Oppression against them took the forms of: extortion, marginalisation, powerlessness, cultural imperialism or violence. ${ }^{9}$ As Amadeusz Krause writes, "despite ideological, theoretical, methodical and political declarations in Poland concerning the assurance for disabled persons of conditions for normal functioning, we are dealing with a systemic and social disability of adulthood of disabled persons" ${ }^{10}$ Over the course of centuries, the attitude of societies towards disabled persons and their families has changed. One may conclude that this process evolved from complete segregation and exclusion towards normalisation and respect for laws through the start-up of activity spanning integration and inclusion. ${ }^{11}$ Aleksander Hulek wrote many times that the best sys-

${ }^{6}$ The Salamanca Statement and Framework for Action on Special Needs Education adopted by the World Conference on Special Needs Education: Access and Quality, UNESCO, Salamanca 1994.

${ }^{7}$ D. Mitel, Sprawdzone metody edukacji specjalnej i właczajacej, transl. by J. Okuniewski, Wydawnictwo Harmonia, Gdańsk 2016, pp. 352-353.

${ }^{8}$ I. Chrzanowska, Pedagogika specjalna, Oficyna Wydawnicza „Impuls”, Kraków 2015, p. 120.

${ }^{9}$ A. Twardowski, Społeczny model niepetnosprawności - geneza, istota, kontrowersje, [in:] K. Barłóg (ed.), Wybrane konteksty i wyzwania wspótczesnej pedagogiki specjalnej, Wydawnictwo UR, Rzeszów 2017, pp. 18-19.

${ }^{10}$ A. Krause, Dorostość w niepetnosprawności intelektualnej, [in:] „NIEPEŁNOSPRAWNOŚĆ. Dyskursy pedagogiki specjalnej. Dorostość osób z niepetnosprawnościa. Różne oblicza", Wydawnictwo UG, Gdańsk 2016, p. 12.

${ }^{11}$ K. Barłóg, Empathic Sensitivity of Children with Special Educational Needs in Inclusive Learning Environment in Poland, [in:] "The New Educational Review", Vol. 53, No. 3, 2018, pp. 273-282. 
tem of education and upbringing for disabled children and youths is one that allows for the satisfaction of various needs. He reminded that historically, the problem of disability was solved through exhaustion, exploitation, isolation and segregation of the disabled from the rest of society. Such persons did not have the right to remain among healthy people. Everything is changing, and the concept of "normalisation" emerges, which means that the duty exists to include disabled persons into normal life, and to ensure such conditions [for them], as fully able people have. This will allow them to develop normally and to have similar achievements just like their healthy colleagues - their peers. ${ }^{12}$ Nowadays, we observe the changes that are taking place not only in the perception of disabled people, their families, but also the respect for many rights, including the right to education, with the assurance of required conditions and with processional support. Is it thus a situation, in which the child with special education needs is just accepted into a school in a typical school environment, or is the expected aid and support secured as well? The objective of the article is an attempt at responding to the question, whether the current image of inclusive education corresponds to its assumptions, or does it rather boil down to simulated actions? Assumptions of integration and inclusion proposed even in the 1970s by Aleksander Hulek do not seem to be fully implemented in the process of inclusion of children with special education needs at mass schools. One also needs to look at the frequently repeated question: Is inclusive education is the most advantageous form of education for every child with special education needs? Is inclusive education and the expectation of changes and successes in children with special education needs is a "fad" today to hide the real needs and all circumstances surrounding this complex, very difficult process of changes and of inclusion?

12 A. Hulek, Integracyjny system ksztatcenia osób niepetnosprawnych, [in:] A. Hulek (ed.), Pedagogika rewalidacyjna, Państwowe Wydawnictwo Naukowe, Warszaw 1977, pp. 493-494. 


\section{Assumptions of inclusive education as a category opposing exclusion}

Education is not just a form of influence to "know, be able to, live together and be" as we know from the report by J. Delors. ${ }^{13}$ In contemporary understanding, education is preparation to become a subject, to tolerance, democratisation, personal and collective safety and security, but also to the protection of life and the natural environment, while maintaining a worthy, decent existence. It is also a path to individual development and self-creation, but also to the creation of preliminary conditions of respect for the rights and dignity as well as equality of chances for everyone. It is thus supposed to be a relatively just equality of chances and opportunities in the struggle for everyone's social status. ${ }^{14}$ Assuming that education is a particular value against social exclusion and that it facilitates processes of establishment of readiness ahead of changes, one needs to conclude that contemporary education, embedded in the context of dynamic, progressing civilisational changes is and should be a factor of establishment of positive changes and transformations for everyone. Already the "inclusion of an excluded person [itself] into the educational process is a symptom of an advantageous change, and constitutes a significant factor of protection". Objectives of education should assume the start-up of behaviour that is advantageous for the health and development of a person". ${ }^{15}$ For children and youths with diverse disabilities, education has a particular significance: It is a chance at their normalisation and better quality of life. Inclusion

${ }^{13} \mathrm{~J}$. Delors (ed.), Edukacja. Jest w niej ukryty skarb. Raport dla UNESCO. Warszawa 1999.

${ }^{14}$ R. Michalak, Edukacja szansa dla osób wykluczonych społecznie, [in:] J. Hoffmann (ed.), Znaczenie edukacji w procesie readaptacji osób wykluczonych w kontekście doświadczeń projektu KPU-NSD. Wydawnictwo Wyższa Szkoła Zawodowa „KADRY DLA EUROPY", Poznań 2008, p. 16.

${ }^{15}$ A. Rosińska, Znaczenie edukacji osób w procesie budowania ich gotowości do prozdrowotnej zmiany, [in:] J. Hoffmann (ed.), Znaczenie edukacji w procesie readaptacji osób wykluczonych w kontekście doświadczeń projektu KPU-NSD, Wydawnictwo Wyższa Szkoła Zawodowa „KADRY DLA EUROPY”, Poznań 2008, p. 37. 
as opposition to social exclusion is a process of changes, with the right to education, learning with peers, common relations and participation of all pupils in education. ${ }^{16,17}$ "Inclusive education is a process that encompasses the transformation of schools and other learning facilities in such a way so that they could serve all children: Both boys and girls, children from ethnic and linguistic minorities, rural dwellers, persons with HIV/AIDS and persons with disabilities and learning difficulties". ${ }^{18}$ The process of inclusion is opposition against the process of exclusion. Exclusion is coupled with discrimination and stripping of rights and privileges, deprivation, resrestitution or marginality. ${ }^{19}$ One could point to factors taken into account in the social exclusion model in the multidimensional perspective. Anna Brzezińska along with a team of researchers makes such a proposition.

Table no 1. Factors taken into account in the multidimensional model of social exclusion according to Levitas and others (2007). Edited by A.I. Brzezińska, J. Pluta, P. Rycielski ${ }^{20}$

\begin{tabular}{|c|c|c|}
\hline Resources & Participation & Quality of life \\
\hline $\begin{array}{c}\text { material } \\
\text { social } \\
\text { access to the sector of public } \\
\text { and private services }\end{array}$ & $\begin{array}{l}\text { in the economic sense } \\
\text { in social life } \\
\text { in the system of education, } \\
\text { knowledge and culture } \\
\text { in the political system and } \\
\text { the civic society }\end{array}$ & $\begin{array}{l}\text { health and happiness } \\
\text { environment of life } \\
\text { crime } \\
\text { safety and conflicts with } \\
\text { the law }\end{array}$ \\
\hline
\end{tabular}

${ }^{16}$ M. Ainscow, T. Booth, Przewodnik po edukacji włączającej. Rozwój kształcenia i uczestnictwa w życiu szkoty, Wydawnictwo Olimpiady Specjalne Polska, Warszawa, 2011.

${ }^{17} \mathrm{~K}$. Barłóg, Inkluzja społeczna, edukacyjna a problemy młodych osób z ograniczeniami sprawności, [in:] „Lubelski Rocznik Pedagogiczny”, Vol. 36, No. 2, 2017, pp. 171-183.

${ }^{18} \mathrm{D}$. Mitchel, Sprawdzone metody w edukacji specjalnej i właczajacej. Strategie nauczania poparte badaniami, transl. by Juliusz Okuniewski. Wydawnictwo HARMONIA, Gdańsk 2016, p. 351.

${ }^{19}$ I. Chrzanowska, Problemy edukacji dzieci i młodzieży z niepetnosprawnością. Regionalna specyfika czy ogólnopolska tendencja. Oficyna Wydawnicza „Impuls”, Kraków 2009.

${ }^{20}$ A. I. Brzezińska, J. Pluta, P. Rycielski (2010) Wsparcie dla osób z ograniczeniami sprawności i ich otoczenia, Wydawnictwo Naukowe SCHOLAR, Warszawa 2010, p. 80. 


\section{The strategy of inclusive education}

In his book "What Really Works in Special and Inclusive Education: Using evidence-based teaching strategies", D. Mitchell distinguishes among twenty-nine strategies, assuming that one of them may be inclusive education, even as a multi-part strategy or megastrategy. ${ }^{21}$ He assumes that if it is implemented correctly, then pupils with special needs should experience advantages both in terms of education as well as in social affairs. Their self-esteem should be improved. Other pupils should also experience educational advantages, but also learn to respect the community, understand ideas of equality and social justice, develop competences, social attitudes and attitudes of caring. Pupils with special education needs have the right to learn together with their fully able colleagues, peers, who do not require particular support, which is in agreement with rules of social equality and justice. Inclusive education is more substantiated for economic reasons, omits costs related to the transport and accommodation of pupils at special facilities, in particular in rural settings. ${ }^{22}$

\section{Examples of research conducted on inclusive education}

One can already find much scientific research on this topic, mainly showcasing the shortcomings, barriers in terms of securing of conditions for pupils with special education needs. For instance, an English study from the year 2004 confirmed that the presence of a fairly large number of pupils with special education needs at ordinary schools has no negative influence on the results achieved by other pupils. Indicated was the significance of such factors as: the

${ }^{21}$ D. Mitchel, Sprawdzone metody w edukacji specjalnej I włączajacej. Strategie nauczania poparte badaniami, transl. by Juliusz Okuniewski, Wydawnictwo HARMONIA, Gdańsk 2016, p. 26.

22 D. Mitchel, Sprawdzone metody w edukacji specjalnej i włączającej. Strategie nauczania poparte badaniami, transl. by Juliusz Okuniewski, Wydawnictwo HARMONIA, Gdańsk 2016, p. 352. 
socio-economic status, the gender, social origin or language. It was confirmed that pupils with special education needs progress within school education, but also within social and personal development. Joint education can correlate positively with the results of all people, mainly in terms of social competences and understanding. Research has shown that special education needs of children can be related to their isolation as well as their low self-esteem and low self-perception ${ }^{23}$.

Other research on factors facilitating or hindering the inclusion of people with disabilities was presented by a research team headed by prof. Anna Brzezińska in the book "Wsparcie dla osób z ograniczeniami sprawności" [Support for people with limited physical abilities]. ${ }^{24}$ Research has shown the context of factors that facilitate inclusion or that hinder it, in a group of people with physical limitations. Stressed was the particular role of the environment of support for the studied persons, meaning: a supporting family, the closest people, acquaintances, friends, neighbours, but also the closeness of supporters; the ability to speak about problems and difficulties, or even a specific style of upbringing. It was assumed that these factors influence the level of participation of those analysed in social life, and as a consequence, they influence not only educational activity but also professional activity and the subjectively high perception of the quality of life, satisfaction with one's financial situation and general satisfaction from life. ${ }^{25}$ The own research conducted together with students as part of projects within the Students' Paedagogues and Special Educators Research Club in the year 2017 encompassed twenty-two public primary schools in the city of Rzeszów. The

23 D.A. Dyson, P. Farrell, F. Polat, G. Hutcheson, Inclusion and pupil achievement, Raport z badań RR5778, London: DIES, 2004, as quoted in: D. Mitel, Sprawdzone meto$d y$ w edukacji specjalnej $i$ wtaczającej. Strategie nauczania poparte badaniami, transl. by Juliusz Okuniewski, Wydawnictwo HARMONIA, Gdańsk 2016.

${ }^{24}$ A.I. Brzezińska, J. Pluta, P. Rycielski (2010) Wsparcie dla osób z ograniczeniami sprawności. Wyniki badań, Wydawnictwo Naukowe SCHOLAR Warszawa 2010.

25 A.I. Brzezińska, J. Pluta, P. Rycielski (2010) Wsparcie dla osób z ograniczeniami sprawności $i$ ich otoczenia, Wyniki badań, Wydawnictwo Naukowe SCHOLAR, Warszawa 2010, pp. 79-91. 
objective of research was a diagnosis of readiness of schools of the city of Rzeszów to take on children with disabilities, but also to satisfy their special needs. ${ }^{26}$ The selection of the area of research was purposeful, and was based on the assumption that in such a large city, the situation of children with special education needs should be more favourable than in small rural schools. The results achieved following the conducted interviews with the headmasters of the studied schools, however, did not prove optimistic. Pupils with special education and health heeds often learn in overcrowded classes, because they number between 21 and 30 pupils, contacts with specialists remain infrequent, mainly in situations of diagnosis of special needs, the determination of the type and scope of support work. The majority of headmasters of the analysed facilities concluded that "the school is, in general, not adapted to the education of children with mobility disabilities, due to, for instance, architectural barriers, even though children with mobility disabilities learn in the classes". In other opinions, one could obtain the information that "the assurance of relevant conditions depends on the individual case of the pupil. The school always tries to provide aid and support for children with special education needs, but a hindrance are financial limitations, limitations of space or the organisation of work of the school itself". Research has confirmed that the decisive majority of teachers concluded post-diploma studies mainly in oligophrenologic paedagogy, but also diverse training courses. There are fewer teachers who have graduated from full master's studies in special education. There is also a group of teachers that have indicated lack of preparation in the area of special education, having finished studies in early education or care and upbringing paedagogy. Hence, the determined project title of "A school friendly to disabled children" was not fully suitable to the presented diagnosis of readiness of schools to provide conditions to satisfy the special needs of disabled pupils at public schools".

${ }^{26}$ K. Barłóg, D. Karcz, J. Kawa, K. Sabat-Zabłotni, Szkoła przyjazna dla dzieci $z$ niepetnosprawnością. Biuletyn gotowości rzeszowskich szkót podstawowych do przyjęcia dzieci z ze specjalnymi potrzebami edukacyjnymi. Wydawnictwo Uniwersytetu Rzeszowskiego, Rzeszów 2017. 


\section{Own research}

A continuation of historic research were own studies conducted in a group of teachers of the Subcarpathian Voivodeship towards the end of 2018 and in the beginning of 2019. The objective of the research was attempt at finding an answer to the question- how do teachers determine and classify difficulties and successes in inclusive education? The study encompassed 65 teachers working at public schools, these were women aged 30 to 54 yars. $100.0 \%$ of them had higher education, $56.0 \%$ of those studied had teaching experience of 25 years or more. The remaining teachers had between five and ten years of teaching experience. The opinions of the teachers on difficulties of working with children with special education needs are presented in table no 1.

Table no 1. Difficulties of inclusive education from the point of view of teachers

\begin{tabular}{|c|l|c|c|}
\hline No. & \multicolumn{1}{|c|}{ Response categories } & N & $\%$ \\
\hline 1 & Overcrowded classes & 22 & 53.0 \\
\hline 2 & Excess number of children with difficulties & 10 & 24.0 \\
\hline 3 & No education aids & 5 & 12.0 \\
\hline 4 & Financial limitations & 7 & 17.0 \\
\hline 5 & Limited access to support & 7 & 17.0 \\
\hline 6 & No support by parents & 5 & 12.0 \\
\hline 7 & Difficulties of children with special needs & 9 & 22.0 \\
\hline
\end{tabular}

Multiple choice questions.

The achieved results confirm that teachers, working with children with special education needs, experience many difficulties: organisational, financial, related to the functioning of the education facility and lack of aid or support. A particular difficulty are overcrowded classes, in which pupils with diverse needs and individual capacities learn, and this is the opinion of half of those studied (53.0\%); the high proportion of children with special education and 
health needs ( $24.0 \%$ of those studied) as well as the difficulties and individual problems of such children themselves (22.0\%). Disturbing is the fact that in many cases the teachers do not get support, be it from the facility or from the outside $(17.0 \%)$, but also from the parents of the children with special education needs themselves. These problems are often compounded by financial limitations $(17.0 \%)$ or even the lack of basic aids or tools $(12.0 \%)$.

Table no. 2. Difficulties in terms of cooperation with parents of children with special education needs

\begin{tabular}{|c|l|c|c|}
\hline No. & \multicolumn{1}{|c|}{ Response categories } & $\mathrm{N}$ & $\%$ \\
\hline 1 & Lack of trust in teacher & 1 & 2.4 \\
\hline 2 & Excess expectations of parents & 5 & 12.0 \\
\hline 3 & No preparation of teachers to cooperate with the parents & 18 & 43.0 \\
\hline 4 & Parental overprotectiveness & 21 & 50.0 \\
\hline 5 & Difficulties of children expecting support & 18 & 43.0 \\
\hline 6 & No understanding for the child's needs and problems & 1 & 2.4 \\
\hline 7 & No engagement in cooperation by the parents & 6 & 14.0 \\
\hline 8 & Difficulties related to cooperation with parents & 2 & 4.8 \\
\hline
\end{tabular}

Multiple choice questions.

The studies confirm unequivocally that teachers working with children with special education needs also experience many difficulties in terms of cooperation with the parents of the children with special education needs themselves; as these parents significantly fail to amend the work through engagement with the child, or are an entity that does not receive the educational and developmental stimuli of the child. Troubling is the fact that teachers do not feel suitably prepared to support parents in their problems and difficulties related to the need to care for a child with special education needs $(43.0 \%)$, that they see the problems of such families $(43.0 \%)$ and frequent overprotectiveness represented by half of the parents of children with special education needs $(50.0 \%)$, or even lack of 
trust for the work of teachers by parents $(2.4 \%)$ or even excess expectations of parents $(12.0 \%)$. Teachers also sometimes perceive the lack of will and engagement by parents (14.0\%). Some of them admit that they have difficulties cooperating with parents of children with special education needs $(4.8 \%)$.

Table no. 3. Difficulties of teachers left without aid or support

\begin{tabular}{|c|l|r|r|}
\hline No. & \multicolumn{1}{|c|}{ Response categories } & N & $\%$ \\
\hline 1 & Impatience & 3 & 7.2 \\
\hline 2 & Helplessness & 21 & 50.0 \\
\hline 3 & Distress & 1 & 2.4 \\
\hline 4 & Dismay & 5 & 12.0 \\
\hline 5 & Fatigue & 9 & 22.0 \\
\hline 6 & No such problems & 9 & 22.0 \\
\hline
\end{tabular}

Multiple choice questions.

The study revealed that some teachers working with children with special education needs who are left without aid and support sometimes experience negative emotions and psychological fatigue, such as helplessness in certain situations $(50.0 \%)$, fatigue $(22.0 \%)$ or dismay (12.0) and even impatience $(7.2 \%)$ or distress $(2.4 \%)$. Of course, a significant number of teachers does not experience such problems $(22.0 \%)$, however the achieved study results can be an important information confirming that some teachers are left without the necessary aid and support and can experience many negative feelings and incidents, helplessness in working with children with special education needs.

The tested teachers include regular professional development among their particular professional successes.

One could confirm that a particular success of teachers working with children with special education needs is regular improvement of own professional competences to achieve more efficient work 
with children with special education needs, in particular through attending post-diploma studies in special education $(48.0 \%)$, but other forms of learning as well: participation in trainings, scientific and educational conferences $(17.0 \%)$, courses and other forms of learning $(9.5 \%)$ or reading professional literature $(81.0 \%)$.

Table no. 4. Forms of improvement of own professional qualifications

\begin{tabular}{|c|l|c|c|}
\hline No. & \multicolumn{1}{|c|}{ Response categories } & N & $\%$ \\
\hline 1 & Attending post-diploma studies & 20 & 48.0 \\
\hline 2 & Participation in trainings, conferences & 7 & 17.0 \\
\hline 3 & Reading specialist literature & 34 & 81.0 \\
\hline 4 & Participation in courses and other forms of learning & 4 & 9.5 \\
\hline
\end{tabular}

Multiple choice questions.

Table no. 5. Successes of children with special education needs in teacher statements

\begin{tabular}{|c|l|c|c|}
\hline No. & \multicolumn{1}{|c|}{ Response categories } & N & $\%$ \\
\hline 1 & Visible positive developmental changes & 26 & 52.0 \\
\hline 2 & Integration with the group & 44 & 88.0 \\
\hline 3 & Visible intellectual development & 26 & 52.0 \\
\hline 4 & Successes in learning & 28 & 56.0 \\
\hline 5 & Visible development of social competences & 44 & 88.0 \\
\hline
\end{tabular}

Multiple choice questions.

The statements by teachers indicate that they appreciate ant successes of children with special education needs - this is the opinion of the decisive majority of teachers. These successes apply mostly to changes in terms of integration with the peer group $(88.0 \%)$, the development of positive attitudes and social behaviour (88.0\%), but also visible successes in learning $(56.0 \%)$, intellectual and general development of the child (52.0\%), in general: visible positive developmental changes $(52.0 \%)$. 
Table no. 6. Successes of teachers in work with children with special education needs

\begin{tabular}{|c|l|c|c|}
\hline No. & \multicolumn{1}{|c|}{ Response categories } & $\mathrm{N}$ & $\%$ \\
\hline 1 & $\begin{array}{l}\text { Diagnosing the needs of children with special educa- } \\
\text { tion needs }\end{array}$ & 38 & 76.0 \\
\hline 2 & $\begin{array}{l}\text { Elimination of difficulties experienced by a child with } \\
\text { special education needs }\end{array}$ & 24 & 48.0 \\
\hline 3 & Motivating to activity and learning & 32 & 64.0 \\
\hline 4 & $\begin{array}{l}\text { Achievement of successes and better grades by a child } \\
\text { with special education needs }\end{array}$ & 34 & 68.0 \\
\hline 5 & $\begin{array}{l}\text { Elimination of barriers and equalisation of chances of } \\
\text { children with special education needs }\end{array}$ & 36 & 72.0 \\
\hline 6 & Special preparation of the teacher & 24 & 48.0 \\
\hline 7 & Aid for a child with special education needs & 44 & 88.0 \\
\hline 8 & Inclusion of the child in the peer group & 18 & 36.0 \\
\hline 9 & Rewarding the child's successes & 36 \\
\hline
\end{tabular}

Multiple choice questions.

The study shows that teachers of public schools also notice many successes when working with children with special education needs, in particular concerning the inclusion of the child in the peer group $(80.0 \%)$, diagnosing the needs and capacities of the child $(76.0 \%)$, achievement of successes and better grades by children with special education needs $(68.0 \%)$, own preparation for working with children with special education needs $(72.0 \%)$, aid for children with special needs $(48.0 \%)$. They are also happy with successes in terms of elimination of difficulties for children with special needs (36.0\%) and in general the equalisation of chances, elimination of barriers and hindrances in terms of satisfaction of special needs and inclusion.

The studies confirm that a significant proportion of teachers at public schools perceives many positive values in working with children with special education needs. Despite certain difficulties, a significant share of these perceive, as their professional success, satisfaction due to setting demanding educational requirements and goals that are achievable by children $(88.0 \%)$, the usage of interest- 
ing methods of work (84.0) and individual perception of the child's needs $(68.0 \%)$. This is also a positive attitude towards the difficulties and special needs of children $(64.0 \%)$; adaptation of the curriculum and time to the individual capacities and needs of the child $(60.0 \%)$ and efficient cooperation with parents (52.0\%), etc.

Table no. 7. Successes in inclusive education in teacher statements

\begin{tabular}{|r|l|c|c|}
\hline No. & \multicolumn{1}{|c|}{ Response categories } & N & $\%$ \\
\hline 1 & $\begin{array}{l}\text { Positive attitude towards the difficulties of children with } \\
\text { special education needs }\end{array}$ & 32 & 64.0 \\
\hline 2 & $\begin{array}{l}\text { A curriculum, pace and time adapted to the needs of } \\
\text { pupils with special education needs }\end{array}$ & 30 & 60.0 \\
\hline 3 & Interesting methods of work & 42 & 84.0 \\
\hline 4 & Interesting education strategies & 18 & 35.0 \\
\hline 5 & Usage of interesting educational and technical resources & 22 & 44.0 \\
\hline 6 & Positive cooperation with specialists & 30 & 60.0 \\
\hline 7 & Efficient, partnerly cooperation with parents & 26 & 52.0 \\
\hline 8 & Individual perception of the child with special needs & 34 & 68.0 \\
\hline 9 & $\begin{array}{l}\text { Faith in the sense of working with children with special } \\
\text { needs }\end{array}$ & 20 & 40.0 \\
\hline 10 & Setting achievable goals & 44 & 88.0 \\
\hline
\end{tabular}

Multiple choice questions.

\section{Conclusion}

The fragmentarily presented results of the scientific research and the theoretical substantiation confirms that the process of inclusive education is a complex one, even though, despite many difficulties, it is already visible, and in certain areas of its execution or educational spaces - efficient. Research confirms that many difficulties remain that the studied teachers have to handle: a high proportion of children with difficulties, overcrowded classes, the needs of the children themselves and of their parents, lack of preparation for 
working with parents, helplessness or fatigue. Despite the fact that the studied teachers confirm a certain fatigue or sometimes helplessness in light of the problems, needs of pupils, they also see the first successes. They admit that many of them already have special preparation, graduated from post-diploma studies in special education, study professional literature, utilise interesting methods of education and therapy, diagnose the special needs of children. As Władysław Dykcik writes, contemporary systemic education does not establish the threat of failure of pupils with special education needs, and frequently many of its intentional activities secure individual subjectivity and personal autonomy of these pupils. referring to guidelines concerning the prevention of discrimination (Inclusion Europe), he reminds of rules setting out the efficiency of activity for people with disability. He assumes that a disabled person is able to have certain achievements. One must reject traditional thinking that the problem lies only in the disabled person, and that it is they that must change so that they could be able to emerge within society. one must conclude that disability is a social issue, hence, the rights of disabled persons must be sanctioned politically. One needs to support the establishment of an identity and culture of disabled persons. Persons with disabilities should find at least a shadow of joy in their disability, and these people should be treated as having control of their own lives 27 . The process of inclusive education, already commenced and already ongoing, requires precise diagnoses, on which positive change and transformation models must be built. Every educational situation should respect the child's dignity and satisfy their individual needs. Particularly important in this regard is the observation of ongoing changes and the offer of systemic support, but also the establishment of a feeling of value of participants $^{28}$. The encountered dilemmas may only be seeming ones.

27 W. Dykcik, Problemy osób społecznie naznaczonych i upośledzonych, [in:] Znaczenie edukacji w procesie readaptacji osób wykluczonych w kontekście doświadczeń projektu KPU-NSD, J. Hoffmann (ed.), Wydawnictwo Wyższa Szkoła Zawodowa „KADRY DLA EUROPY", Poznań 2008, p. 58.

28 A. Rosińska, Znaczenie edukacji w procesie budowania gotowości do zmiany, [in:] Znaczenie edukacji w procesie readaptacji osób wykluczonych w kontekście doświadczeń 


\section{Bibliography}

[1] Ainscow M., Booth T., Przewodnik po edukacji włączającej. Rozwój ksztatcenia i uczestnictwa w życiu szkoty, Wydawnictwo Olimpiady Specjalne Polska, Warszawa 2011.

[2] Barłóg K., Empathic Sensitivity of Children with Special Educational Needs in Inclusive Learning Environment in Poland, [in:] "The New Educational Review", Vol. 53, No. 3, 2018.

[3] Barłóg K., Inkluzja społeczna, edukacyjna a problemy młodych osób z ograniczeniami sprawności, [in:] „Lubelski Rocznik Pedagogiczny”, Vol. 36, No. 2, 2017.

[4] Barłóg K., Karcz D., Kawa J., Sabat Zabłotni K., Szkoła przyjazna dla dzieci niepetnosprawnościa, Wydawnictwo Uniwersytet Rzeszowski, Rzeszów 2017.

[5] Bayliss P., Edukacja włączająca, [in:] J. Bogucka, D. Żyro (ed.), Od nauczania integracyjnego do szkoty równych szans, Wydawnictwo PPP MEN Warszawa 1997.

[6] Brzezińska A.I., Pluta J., Rycielski P., Wsparcie dla osób z ograniczeniami sprawności. Wyniki badań. Wydawnictwo Naukowe SCHOLAR, Warszawa 2010.

[7] Chrzanowska I., Pedagogika specjalna. Od tradycji do wspótczesności, Oficyna Wydawnicza „Impuls”, Kraków 2015.

[8] The Salamanca Statement and Framework for Action on Special Needs Education adopted by the World Conference on Special Needs Education: Access and Quality, UNESCO, Salamanca 1994.

[9] Delors J., Edukacja. Jest w niej ukryty skarb. Raport dla UNESCO Międzynarodowej Komisji ds. Edukacji dla XXI wieku, Warszawa 1999.

[10] Dykcik W., Problemy osób spotecznie naznaczonych i upośledzonych, [in:] J. Hoffmann (ed.), Znaczenie edukacji w procesie readaptacji osób wykluczonych w kontekście doświadczeń projektu KPU-NSD, Wydawnictwo WSZ „KADRY DLA EUROPY", Poznań 2008.

[11] Hulek A., Integracyjny system kształcenia osób niepetnosprawnych, [in:] A. Hulek (ed.), Pedagogika rewalidacyjna, Państwowe Wydawnictwo Naukowe, Warszawa.

[12] Krause A., Dorostość w niepetnosprawności intelektualnej, [in:] "NIEPEŁNOSPRAWNOŚĆ. Dyskursy pedagogiki specjalnej. Różne oblicza", Wydawnictwo Gdańsk 2016.

[13] Michalak R., Edukacja szansa dla osób wykluczonych społecznie, [in:] J. Hoffmann (ed.), Znaczenie edukacji w procesie readaptacji osób wykluczonych w kontekście doświadczeń projektu KPU-NSD, Wydawnictwo WSZ „KADRY DLA EUROPY”, Poznań 2008.

projektu KPU-NSD, J. Hofmann (ed.), Wydawnictwo Wyższa Szkoła Zawodowa „KADRY DLA EUROPY”, Poznań 2008, pp. 29-40. 
[14] Mitel D., Sprawdzone metody w edukacji specjalnej i właczajacej. Strategie nauczania poparte badaniami, transl. by Juliusz Okuniewski, Wydawnictwo HARMINIA, Gdańsk 2016.

[15] Rosińska A., Znaczenie edukacji w procesie budowania gotowości do zmiany, [in:] J. Hoffmann (ed.), Znaczenie edukacji w procesie readaptacji osób wykluczonych w kontekśsie doświadczeń projektu KPU-NSD, Wydawnictwo WSZ KADRY DLA EUROPY, Poznań 2008.

[16] Smith D.D., Pedagogika specjalna. Podręcznik akademicki, sc. ed. A. Firkowska-Mankiewicz, G. Szumski, Wydawnictwo APS Warszawa, No. 1, 2009.

[17] Szumski G., Wokót edukacji włączającej. Efekty ksztatcenia uczniów z niepetnosprawnościa intelektualna w stopniu lekkim w klasach specjalnych, integracyjnych i ogólnodostępnych, Wydawnictwo Akademii Pedagogiki Specjalnej, Warszawa 2010.

[18] Twardowski A., Społeczny model niepetnosprawności - genez, istota, kontrowersje, [in:] Wybrane konteksty i wyzwania wspótczesnej pedagogiki specjalnej, [in:] K. Barłóg (ed.), Wydawnictwo Uniwersytetu Rzeszowskiego, Rzeszów 2017.

[19] Zamkowska A., Wsparcie edukacyjne uczniów z upośledzeniem umystowym w stopniu lekkim w różnych formach kształcenia na pierwszym etapie edukacji. Wydawnictwo Politechniki Radomskiej, Radom 2009. 